\title{
Desabafo de um Técnico de Administração
}

«As mazelas do Serviço Público, no que concerne à Administração de Pessoal, são originárias de um conjunto de três fatôres: Lotação, Classificação e Retribuição de Cargo.»

\section{Hugo Luiz Gurjão de Mello}

I

NICIAR com tal afirmativa consideraçôes em tôrno de tão complexo tema. envolvendo-o, como um todo composto de três importantes fatôres da Administração de Pessoal, demanda, sem dúvida, explicações imediatas, a fim de evitar zombarias e incompreensões, tanto da parte dos governantes como dos governados - entre êstes os servidores públicos, nem todos tão cônscios de sua própria importância, nem tão profundos conhecedores dos negócios públicos, quanto se julgam.

Eis porque nos apressamos a adiantar sabermos de outras fontes de dificuldades que inundam as repartições públicas de papéis e de pessoas - de pessoas que fazem papéis e de papéis que fazem pessoas.

O enfoque, todavia, parece-nos sobremodo oportuno nesta fase em que a Administração está sofrendo reformas de base, de comportamento, de diretrizes; os analistas procurando emendar todos os esquemas de tarefas inadequadas, inclusive com a faculdade de remanejar a mão-de-obra ociosa.

Ora, indubitàvelmente, essa louvável e necessária atividade administrativa só poderá redundar em êxito, em face dos fatôres de ecologia, na proporção em que, física e espiritualmente, dêsse movimento reformista participar o povo - notadamente o funcionalismo público. Participação que não seja, é óbvio, negativa nem indiferente - manifestações tais hão naturalmente de solapar, de plano, qualquer que seja o programa de reforma imaginado.

Participação positiva, porém, depende do sistema de comunicações empregado nesse sentido, com o intuito honesto e desenganado de fazer o plano esquemático conhecido e compreendido por todos os interessados, a fim de que, conscientizados das próprias 
responsabilidades, possa o elemento humano que o integra cooperar para o êxito do projeto, apesar da deficiência instrumental de que nos ressentimos.

Dir-se-á, então, que a Reforma Administrativa, preconizada pelo Decreto-lei $n^{\circ} 200$, de 1967, nascida dentro de gabinete e mantida inconcessa até sua publicação, padece de pecado original. $\mathrm{Na}$ verdade, imposta, quando todos a desejavam, complexa, onde se impunha simpleza, infindável, embora a situação do País demande meios imediatos, tôda sorte de críticas poderia merecer, só que não mais é oportuno fazê-lo. Cumpre, antes, ressaltar-lhe as virtudes, que as há muitas, bastando citar o rol de diretrizes sôbre o funcionalismo. Resta, agora, até por dever cívico, acumulável com o dever funcional, colaborar, sem espírito meramente revisionista, mas tenazmente executivo, para a implantação e êxito do plano pilôto, estabelecido pelo mencionado Decreto-lei número 200, de 1967.

Ei-lo batizado. Urge, pois, enfrentar as entropias com denodo e otimismo, buscar os modelos e instrumentos de pesquisa, analisar sem o formalismo retrógrado, comparar suas tendências predeterminadas, observando tôda amplitude de variação, equacionando os problemas para solucioná-los em bases humanas, porém firmes, conciliando os interêsses individuais com os coletivos, sem perder de vista que os interêsses da Administração se devem comover mais com os de todos do que como o de um.

Estas reflexões valem para introduzir o assunto, deixando bem claro que o abordamos sem pretensões de defender tese ou reformular conceitos e princípios administrativos básicos, mas com o desejo puro de colaborar para o esclarecimento de problemas diversos, mas tão interligados entre si que, ao nosso ver, sòmente poderão ser solucionados em conjunto. Nossa modesta contribuição é despida do brilho que a citação de autores famosos empresta a trabalhos da espécie; calcada exclusivamente nos doze anos em que, servindo à Divisão do Regime Jurídico do Pessoal, do DASP, desde a velha D.P. seccionada pela Lei $\mathrm{n}^{\circ} 3.780$, de 1960 , temos visto e sentido, em tôda a sua intensidade, os múltiplos problemas de pessoal, provenientes não só, em particular, de falhas do Estatuto dos Funcionários, atual mas desatualizado. pedindo reexame, como também, em geral, da legislação específica, desordenada, confusa, torrencial, paliativa.

Com apoio em nossa experiência pessoal, extraímos denominadores comuns que nos facultaram equacionar, como um todo em seu conjunto, em têrmos de lotação, classificação e retribuição de cargos públicos, o problema originário da administração de pessoal - digamos - originário, não o único ou o principal, nem mesmo o pior da espécie. 


\section{LOTAÇÃO}

A matéria tem definição estatutária: «Entende-se por lotação o número de servidores que devem ter exercício em cada repartição» (art. 33 da Lei $n^{\circ} 1.711$, de 1952). No artigo seguinte, que melhor fôra parágrafo único daquela definição, é estabelecido que o funcionário não poderá ter exercício em repartição diferente da em que estiver lotado, proibição, entretanto, enfraquecida em seu próprio berço, pois o parágrafo único, dêsse mesmo artigo, libera o tumulto permitindo que tal afastamento, além dos casos expressamente previstos, possa ocorrer mediante prévia autorização do Presidente da República. Ninguém tire daí conclusões apressadas - não criticamos o arbítrio de Sua Excelência. Raciocinemos. Em primeiro lugar, lotação, na temática estatutária, carece de conotações, sem as quais se desfigura a inteligência do dispositivo, pràticamente se desfaz a validade do preceito. Fala-se, ali, em números, mas, òbviamente, não se tem em vista mera questão de quantidade, mas também de qualificação, de especialização, de colocação.

Alegar-se-á que, à época da elaboração estatutária, não havia ainda plano de classificação de cargos, cuja feitura foi então determinada (art. 259 do E.F.), não cabendo falar-se em especificação de classes. Tal argumento, válido então, perdura ainda hoje, passados quinze anos, sete dos quais vividos à soleira do Plano de Classificação de Cargos (Lei $n^{\circ} 3.780$, de 1960). Tal fato, por si só merecedor de comentários marginais que adiamos para outra oportunidade, serve para mostrar quão intimamente ligados estão os aspectos em exame, mas não justifica a balbúrdia em que se encontra o funcionalismo público - abrangendo essa expressão tôdas as categorias de servidores, incluída também aquela que a Administração insiste em desconhecer a dos serviços prestados mediante recibo, embora a ela recorra tanto quanto às demais. Bem, não justifica mas explica. Ignorando a Administração a lotação ideal de seus órgãos - no seu conceito mais completo, isto é, expressa em qualidade e quantidade realmente necessárias ao funcionamento de cada repartição, tem sido quase impossivel controlar a invasão de pessoal deficientemente escolhido, cujo número, por mais elevado que seja, não logra cobrir o campo de ação que seria fàcilmente dominado por alguns funcionários devidamente selecionados.

As conseqüências, sob êsse aspecto, repercutem em cadeia, quanto mais o Poder Executivo cogita de coibir nomeações e admissões, a fim de limitar as despesas com o funcionalismo, partindo, talvez, da suposição de que o deficit orçamentário do País é devido ao grande número de desocupados que ocupam cargos públicos. 
Essa crença, aliás, parece enraizar-se na mente dos Supremos Mandatários, tão logo começam a sentir o pêso da Faixa Presidencial e provoca sempre reação que, sem embargo de ser produzida com a melhor intenção possível, é traída pelos meios adotados, pelas medidas restritivas tomadas sem o profundo exame das causas e concausas, efeitos e defeitos. Quando Sua Excelência quiser tirar os óculos mágicos que tão distorcidas imagens tem mostrado aos veneráveis antecessores, para ver o verdadeiro panorama, basta simplesmente confrontar a verba orçamentária consumida pelas despesas com pessoal em sua totalidade, com o subtotal efetivamente gasto em razão dos cargos públicos civis, já originàriamente reduzidos, periòdicamente suprimidos, em progressiva vacância, sem o correspondente provimento. Quem o faz, fica admirado ante a insignificância do montante despendido com os ocupantes de cargos em comparação com as dotações para representação de gabinete, que não é paga só ao funcionário, mas também e principalmente a quem não tem vínculo com o serviço público ou é militar; em confronto com as dotações de pessoal temporário, iniludivelmente permanente, para não falar de verbas globais que custeiam os serviços de terceiros, válvula de escape utilizada para admitir pessoal sem o conhecimento do Presidente da República. Sua Excelência, com certeza, ficaria perplexo se avaliasse quantos contingentes de pessoal, pgr essa forma admitidos, se aglutinam em tôrno de repartições que reclamam falta de funcionários. E quanto remorso e arrependimento sentiria Sua Excelência pelo minimo de hesitação que tenha retardado a assinatura de decretos de nomeação de candidatos habilitados em concursos, numa República que se vangloria de defender o sistema do mérito no bôjo de sua Constituição.

Impende, novamente, definir nossa posição para que não se infira destas considerações, nem de longe, qualquer crítica ao Govêrno ou às instituições públicas. Nada disso. Nosso desejo como Técnico de Administração é mostrar o caminho sem rodeios, sem temores, sem veredas enganosas. Nada temos também contra os servidores trabalhistas ou seja lá qual fôr a sua categoria. O que almejamos é desfazer equivocos de tal forma enraizados na Administração que já alguns observadores os consideram naturais e necessários, enquanto outros, embora reconhecendo o prejuízo, os têm na conta de irreparáveis e cruzam os braços.

Até pelo contrário. Se fôra pośsível predeterminar-se a verdadeira lotação das repartições públicas, não hesitaríamos em propor dispositivo legal para tranqüilizar a situação dêsse batalhão de servidores «temporários» e «de recibo» que aos solavancos, vão mantendo o ritmo da Administração, «passinho prá frente, passinho prá trás», num compasso de espera sem fim. Não aconselhariamos, é claro, a transformação de ninguém em funcionário público - seriam, todos os considerados úteis, contratados, 
em caráter permanente, sem concurso, na forma da legislação trabalhista, a qual para servir de codificação uniforme para empregados públicos e privados haveria de sofrer sensíveis alterações. Tal aproveitamento, sem dúvida, seria feito em caráter excepcional, tão-sòmente para regularizar as situações atuais, sem prejudicar a norma vigente que exige habilitação em concurso, mesmo para as admissões com base na legislação trabalhista. Apenas, convém assinalar, impor-se-ia aparelhar a Divisão de Seleção e Aperfeiçoamento, a fim de que houvesse sempre em estoque pessoal habilitado, fôsse qual fôsse a mão-de-obra requerida, bem como racionalizar os esquemas de provas, para adequá-los à dinâmica necessária e à objetividade indispensável.

Inúmeras as vantagens que dai redundariam, Talvez, inclusive, aberta a possibilidade de opção para os atuais funcionários, muito em breve bastasse a aludida codificação trabalhista para reger todos os trabalhadores do País, inclusive no que concerne à previdência social.

Por outro lado, estabelecidas as normas racionais para atender à dinâmica da lotação - a ideal - poderia o Govêrno, êle que sabe das suas reais necessidades, criar livremente empregos públicos, afastado o perigo do afilhadismo pela exigência de concurso para o respectivo provimento, bem como suprimi-los quando desnecessários, ou trocar de ocupantes quando conveniente, sem as amarras do vínculo funcional.

Outrossim, estabelecida a real lotação, nenhuma repartição necessitaria requisitar servidores de outra, bem como desapareceria a necessidade de remoção, a de transferência e a da readaptação, problemas que seriam resolvidos através de novas admissões - sem prejuizo quer para a administração quer para os servidores.

\section{CLASSIFICAÇÃO}

Somos daqueles que consideram o Plano de Classificação vigente meritório em confronto com o caos de que se ressentia a matéria anteriormente. Entretanto, os fatos voltam a demandar novos moldes de classificação, já agora com tôdas as perspectivas de êxito, amadurecido que está o assunto. Ademais, parece-nos sobremodo importante a tentativa de reconstruir o plano de classificação à margem do de retribuição. Não há incoerência de nossa parte defendendo tratamento autônomo para êsses planos quando os consideramos tão interligados que recomendamos o exame em conjunto. O que impende ficar bem esclarecido é a necessidade de classificar as atividades sem pensar em têrmos de retribuição. É claro que a cada encargo corresponderia a devida paga que seria mais ou menos equilibrada, mas $o$ que queremos dizer é que ninguém deveria sentir-se diminuído, menosprezado, humilhado, desajustado em face do vencimento-base de 
seu cargo. O que desejamos expressar é a necessidade de o servidor público sentir orgulho de sua profissão, não importa as atribuições que desempenhe no exercício de suas atividades, em vez de ter vergonha de chegar à velhice ocupando êste ou aquêle cargo de nivel inferior.

Há, evidentemente, tôda uma gama de diversificações a serem examinadas, agrupadas ou eliminadas quando se classifica seja lá o que fôr, quanto mais cargos públicos! No entanto, seria incabivel um trabalho tão simplório - meramente anunciativo - descer a minúcias sôbre o assunto. Objetivamos apenas vender a idéia. O modo de usá-la fica a débito de outra oportu-
nidade.

\section{RETRIBUIÇÃO}

A começar pela falta de numerário suficiente, êste terceiro fator poderia alimentar milhares de controvérsias, inclusive, é óbvio, a respeito da solução que recomendamos. A renúncia, porém, ao sabor da discussão impõe-se porque alheia ao objetivo de lançar o míssil sem obrigar ninguém a ser passageiro.

Cuidamos apenas de completar o pensamento iniciado quando falamos de classificar à revelia da retribuição. É fácil verificar que a escala salarial, cujo gasto absoluto é enorme, equilibra a balança agrupando nos niveis mais baixos a grande maioria de servidores, enquanto sustenta no ápice o pequeno número restante, deixando a descoberto tôda a faixa média. Partindo daí, acreditamos razoável dividir o total da despesa, para com metade distribuir todos os servidores nessa zona intermediária, mais ou menos nivelados em seus vencimentos básicos, aplicando a outra parcela dos gastos totais, para a concessão de gratificação a ser concomitantemente criada para premiar objetivamente aos que mais se destacassem por seus méritos pessoais. A essa gratificação poderíamos chamar, por exemplo, de gratificação pela eficiência e produtividade.

A execução da medida demanda fatalmente outras tantas. quer complementares, quer colaterais para apoio, verbis gratia, a criação de comissões de eficiência e produtividade; a incorporação ao vencimento individual da média das gratificações porventura auferidas durante determinado período; treinamento especial de direções e chefias; a alteração dos critérios de promoção - a de antigüidade seria automática através de acréscimo percentual incorporado aos vencimentos para todos os efeitos, de tantos em tantos anos de serviço; suprimida, em conseqüência, a gratificação qüinqüenal, e tantas outras providências mais, inclusive quanto a dispositivos a introduzir ou modificar na legislação trabalhista para adaptá-la ao programa.

Todavia, não cabe aqui discutir pormenores de execução lográssemos equacionar o problema já seria bastante. Tentamos 
ir além, indicando o esquema básico de reforma e o ponto de partida para desenvolvê-lo; pelo menos é o que pensamos fazer.

\section{EM CONCLUSAO}

Lògicamente, a grande objeção a tudo que dissemos seria a dificuldade de encontrar o modus faciendi.

Como ressaltado, o êxito do plano está diretamente ligado ao sistema de comunicações previsto no planejamento, a fim de vencer as entropias naturais, visto como para alcançar o desideratum não bastaria a análise dos regulamentos e regimentos, quase sempre carecendo revisão, para adequá-lo às realidades administrativas. Indispensável, sim, seria a participação honesta de todo servidor público, quiçá de qualquer cidadão, de um lado indicando suas próprias atribuições em particular e as finalidades da repartição em geral, de outro anotando as dificuldades, a burocracia, os obstáculos $e$ as deficiências encontradas na execução dos serviços, elementos que os analistas examinariam para diagnosticar os males que os técnicos deverão sanar.

Nesse sentido, para ponto de partida, recomendariamos, como se estivéssemos na estaca zero, o emprêgo do velho método dos sete «ww» (who, whom, what, why, way, where, when), tão usado em organização e sempre tão útil em quase tôdas as situações de vida, tanto que a êle nos reportamos, não em função de OSM, mas lembrados de nossa primeira lição jornalística.

Assim, o questionário que serviria de base tanto para a lotação, como para o estudo dos problemas ligados à classificação e à retribuição, versaria em tôrno de «quem», "a quem», «o que», «por que», «como», «onde», e «quando», e seria distribuído a tôdas as repartições e preenchido por todos os servidores, ou partes que o desejassem fazer.

Para atingir, através da análise, os diferentes objetivos da pesquisa, bastaria dirigir o exame de acôrdo com suas finalidades, visto como cada «w» requererá variações, anotações e conotações, respostas e indagações a serem minuciosa e casuìsticamente avaliadas por comissões e subcomissões, especialmente criadas para êsse fim. Daí ser fácil destacar o «w» desejado em confronto com os demais, de acôrdo com a importância que mereçam: se tratamos de lotação, pomos em evidência o «onde»; se o problema é de classificação teremos, em relêvo, o «o que»; se queremos aferir os valôres da gratificação de eficiência ou produtividade, daremos especial atenção ao «como», e assim por diante, fazendo tôdas as combinações possiveis, antes de tirarmos as conclusões.

Quimera? Utopia? Quem sabe? Uma coisa dizemos para os que consideram isto ato de ópera-bufa: esta é a tendência e, mais cedo ou mais tarde, êste será o caminho. 